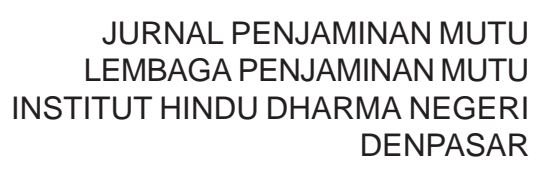

\title{
MENDIDIK LEWAT LITERASI UNTUK PENDIDIKAN BERKUALITAS
}

\author{
Oleh \\ I Made Ngurah Suragangga \\ SMPN 5 Abang Karangasem \\ msuragangga@yahoo.com
}

Diterima 27 Desember 2016, direvisi 01 Januari 2017, diterbitkan 31 Agustus 2017

\begin{abstract}
Culturally Indonesian society does not have a high literacy culture. The results of the research programfor International Student Assessment PISA) mentions, cultural literacy rate of Indonesian society the second worst from 65 countries that are examined in the world. Indonesia occupies the sequence to 64 from 65 countries. While Vietnam thus occupy the century. On the same research, PISA also put the position of the read the students of Indonesia in order to 57 from 65 countries that are examined. Indonesia has experienced an emergency literacy rate. The culture of literacy must be forced and accustomed to become the culture. This literacy culture will affect the quality of education and human resources that are produced. The problem of the low literacy rate, especially in the education line, not only the responsibility of the government. Needed a serious and sustainable synergy, both in the family, schools, universities, even the community to realize that literacy become main culture.
\end{abstract}

Keywords: literacy, culture, education.

\section{PENDAHULUAN}

Melihat perkembangan dunia teknologi informasi saat ini yang tidak selamanya berdampak positif, membuat praktisi pendidikan merasa khawatir. Salah satu kekhawatiran yang masih belum terobati yaitu rendahnya minat baca siswa sekolah di Indonesia. Tahun-tahun sebelumnya, ketika buku masih menjadi satu-satunya sumber bacaan, tidak membuat generasi Indonesia menjadikan kegiatan membaca sebagai satu kebutuhan dalam hidup. Terlebih lagi ketika dunia ini telah dikuasai teknologi informasi yang memungkinkan seseorang untuk mendapatkan ilmu pengetahuan dari berbagai media, peringkat Indonesia dalam hal membaca masih sangat rendah. Kini, buku bukan menjadi beban dengan hadirnya buku eleltronik yang bisa diakses kapanpun, dimanapun, dan dalam situasi apapun. Kegiatan membaca tidak 
menjadi prioritas di negeri ini. Apa yang sebenarnya salah dalam sistem pendidikan di Indonesia? Mengapa membaca buku justru sangat sulit dilakukan dan dibiasakan oleh generasi muda?

Dunia yang kian kompetitif ini, menuntut generasinya untuk cerdas, kreatif, dan inovatif. Semua keterampilan itu bisa diwujudkan, salah satunya melalui kegiatan membaca kreatif. Tuntutan abad ini membuat generasi muda haus akan bacaan baik dari dalam maupun luar negeri. Membaca mungkin kegiatan yang mudah dilakukan, namun susah untuk dijadikan kebiasaan. Bosan, jenuh, cepat menghampiri ketika mulai melakukan kegiatan membaca, sehingga generasi muda merasa bahwa membaca merupakan kegiatan yang membosankan. Apalagi dizaman sekarang ini dimana semua hal bisa divisualisasikan menjadi grafis sehingga mengurangi minat baca masyarakat. Contohnya ketika sebuah novel fiksi remaja yang dijadikan film layar lebar, kebanyak remaja lebih menyukai menonton filmnya tanpa membaca novelnya. Hal tersebut dikarenakan efisien waktu dimana mereka bisa memahami isi cerita hanya memerlukan waktu sekitar 1,5-2 jam dengan menontonnya daripada membaca novel tersebut berhari-hari. Akan tetapi ada beberapa hal yang tidak bisa digrafiskan begitu saja seperti mempelajari ilmu pengetahuan. Ha itu tidak bisa dimengerti ketika menontonnya saja melainkan harus perlu membaca berulang-ulang bahkan harus mempraktikannya agar apa yang dibaca bisa terserap oleh otak. Hal inilah yang kerap menjadi hal sepele yang dilakukan masyarakat tanpa mengetahui arti dari pentingnya membaca.

Di bidang membaca akademik, remaja memiliki sisi lain yang juga memprihatinkan. Ketika mahasiswa semester akhir berniat membaca sebuah jurnal ataupun tulisan ilmiah mereka hanya akan langsung melihat bagian akhir dari kesimpulan jurnal atau tulisan ilmiah tersebut tanpa membaca bagaimana proses yang terjadi ketika mendapatkan kesimpulan seperti itu. Hal sepele tapi sangat berakibat fatal bagi penulisan karya ilmiah kedepannya, bayangkan saja ketika seseorang ingin melakukan sebuah percobaan di lab tanpa membaca keseluruhan isi prosedur bisa saja hal yang tidak boleh dilakukan malah dilakukan sehingga hal-hal yang tidak diinginkan bisa saja terjadi dan akan merugikan diri sendiri. Di zaman sekarang ini, remaja membaca buku apabila sedang membutuhkan sumber untuk mengerjakan tugas. Fenomena seperti ini juga sering terjadi saat seorang mahasiswa sedang menyusun tugas akhir atau skripsi. Maka dari itu kebiasaan membaca harus selalu dibiasakan mulai sejak dini. Keterampilan membaca dapat meningkatkan kemampuan seseorang untuk memahami berbagai konsep dengan mudah. Hal ini mengembangkan keterampian berpikir kritis pada anak-anak. Memahami konsep dan pemikiran kritis adalah dua kualitas penting dari seorang individu yang sukses. Selain itu, membaca juga meningkatkan kosa kata seseorang, perintah pada bahasa, dan kemampuan komunikasi. Trend menunjukan bahwa seseorang yang membaca mampu berkonsentrasi pada pelajaran mereka dan lebih baik daripada mereka yang tidak. Kemampuan membaca secara langsung berhubungan dengan kemampuan menulis yang baik, sebab orang yang jarang membaca akan mengalami kesulitan dalam menemukan kosa kata ketika menulis.

Untuk meningkatkan mutu pendidikan dan sumber daya yang berkualitas yang dihasilkan dalam proses pembelajaran, pemerintah melakukan terobosan dengan mengadakan gerakan literasi sekolah, yaitu gerakan massal untuk menumbuhkan gemar literasi guna memenuhi kebutuhan akan informasi dan bacaan bagi generasi emas yang dimiliki bangsa ini. Langkah nyata diperlukan untuk mulai peka terhadap pendidikan, yaitu melalui literasi seseorang dapat terdidik dengan baik. 


\section{PEMBAHASAN}

\subsection{Budaya Literasi}

Di kawasan kota Denpasar pada hari sekolah saat jam istirahat menghadirkan pemandangan yang memprihatinkan. Kebanyakan remaja tidak bisa mengalihkan perhatiannya pada telepon genggam dan bergosip dengan teman sekelas. Perpustakaan sekolah lebih sepi dibandingkan halaman sekolah. Pengunjung perpustakaan di kala istirahat bisa dihitung dengan jari. Perpustakaan yang sepi dan damai ini kadang menjadi tempat terbaik untuk remaja sekolah menghabiskan waktu untuk tidur sesaat. Kondisi ini sudah berlangsung lama. Generasi saat ini memiliki alasan mengapa buku bukan menjadi satusatunya bahan bacaan. Remaja berasumsi bahwa ilmu pengetahuan bisa didapat dan diakses dengan mudah lewat telepon genggam yang super ajaib menurut mereka. Lihat saja senyatanya, generasi sekolah hanya sibuk bermain media sosial dan terbuai dengan segala aktivitas dunia maya yang seolah merenggut waktu-waktu terbaik untuk membaca hal-hal yang bermanfaat baik.

Berdasarkan sensus Badan Pusat Statistik (BPS) di 2006 menunjukkan 85,9 persen masyarakat memilih menonton televisi daripada mendengarkan radio (40,3 persen) dan membaca koran (23,5 persen). Masyarakat Indonesia belum terbiasa melakukan sesuatu berdasarkan pemahaman dari membaca. Masyarakat Indonesia belum dapat mengaktualisasikan diri melalui tulisan. Membaca dan menulis belum menjadi budaya dan tradisi bangsa Indonesia. Masyarakat lebih familiar dengan media visual (menonton), verbal (lisan) atau mendengar dibandingkan membaca, apalagi menulis. Kondisi di atas tidak hanya pada kalangan awam (masyarakat umum), di lingkungan pelajar dan pendidikan tinggi pun masih jauh dari apa yang disebut budaya literasi yang baik. Kalangan generasi muda belum tertanam kecintaan membaca buku, selain sebatas membaca status atau keterpaksaan adanya tugas. Bahkan guru dan dosen, tidak sedikit dari mereka yang juga sama keadaanya. Tidak sulit untuk mengidentifikasi secara lebih riil bahwa masyarakat Indonesia belum memiliki tradisi literasi yang baik. Di kawasan kota Denpasar, misalnya. Berjalanlah setiap hari ke setiap sudut kelurahan atau kampung, amatilah setiap rumah di saat waktu-waktu senggang atau saat pemberlakuan jam belajar masyarakat ditetapkan. Pemandangan yang terlihat adalah rumah-rumah yang tetap menghidupkan televisi saat jam belajar. Perpustakaan daerah yang telah ditata sedemikian rupa di kota Denpasar juga seperti mati suri. Warga yang cuek dengan seluruh aturan jam belajar atau bahkan tidak ada imbauan pemberlakukan Jam Belajar masyarakat. Tentang hal ini, tidak perlu mencari siapa yang salah dan paling bertanggung jawab atau bahkan menyalahkan pemerintah. Karena sesungguhnya, budaya sadar literasi memang bukan kondisi yang bisa terwujud secara tibatiba dan instan.

\subsection{Dipaksa untuk Terbiasa Membaca kemudian Mahir Menulis}

Dalam hal sadar literasi untuk generasi muda, pemerintah sebenarnya sudah memulai dengan misalnya sejak akhir tahun 2015. Kementerian Pendidikan dan Kebudayaan (Kemendikbud) telah meluncurkan program unggulan bernama Gerakan Literasi Bangsa (GLB) yang bertujuan untuk menumbuhkan budi pekerti remaja melalui budaya literasi (membaca dan menulis). Ikhtiar pemerintah melahirkan kebijakan tersebut tentu adalah niat yang baik. Hanya saja, ketika sebuah kebijakan hanya sebagai formalitas dan program kerja saja, tentu tidak akan maksimal. Pemerintah seharusnya juga mengawal sekaligus mengevaluasi, sehingga program dapat berjalan dengan maksimal dan sesuai dengan kondisi di lapangan. Salah satunya misalnya mendorong dan mengintervensi lembaga-lembaga 
pemerintah dan swasta, yang memiliki ruang tunggu untuk pro aktif menyediakan bahan bacaan, seperti kantor kelurahan, kecamatan, puskesmas, perbankan, koperasi, rumah makan, atau lembaga-lembaga sejenis lain, yang meniscayakan pengunjungnya untuk menunggu. Bukan menyediakan televisi di ruang tunggu. Ini memang tidak mudah, melainkan harus dipaksa untuk terbiasa membaca. Sehingga, ketika tempat-tempat tersebut difasilitasi ruang baca, maka waktu menunggu bisa dimanfaatkan untuk membaca. Bagaimanapun aktivitas literasi merupakan salah satu aktivitas penting dalam hidup. Sebagian besar proses pendidikan bergantung pada kemampuan dan kesadaran literasi. Budaya literasi yang tertanam dalam diri generasi muda mempengaruhi tingkat keberhasilan baik di jenjang pendidikan maupun dalam kehidupan bermasyarakat.

Dr. Roger Farr (1984) menyebut bahwa "reading is the heart of education". Membangun Budaya Sadar Literasi Dr. Ngainun Naim, dalam buku "Geliat Literasi (2015)", dalam kata pengantarnya menulis, bahwa untuk menciptakan kemajuan peradaban suatu daerah salah satunya dengan menumbuhkembangkan tradisi literasi. Dalam konteks ini generasi muda yang juga generasi pembelajar seharusnya dapat mengambil peran aktif menjadi motor penggerak untuk melajunya budaya sadar literasi di lingkungannya masingmasing agar lebih massif. Tentang literasi, khususnya menulis, Hernowo (2005) dalam bukunya "Mengikat Makna" menyebut bahwa menulis dapat membuat pikiran seseorang lebih tertata, membuat seseorang bisa merumuskan keadaan diri, mengikat dan mengonstruksi gagasan, mengefektifkan atau membuat seseorang memiliki sugesti positif, membuat seseorang semakin pandai memahami sesuatu (menajamkan pemahaman), meningkatkan daya ingat, lebih mengenali diri sendiri, mengalirkan diri, membuang kotoran diri, merekam momen mengesankan yang dialami, meninggalkan jejak pikiran yang sangat jelas, memfasihkan komunikasi, memperbanyak kosa-kata, membantu bekerjanya imajinasi, dan menyebarkan pengetahuan. Bahkan berdasarkan riset yang yang dilansir baru-baru ini di Eropa bahwa dengan membaca dapat mengurangi dua kali risiko terserang penyakit Alzheimer (pikun). Artinya, budaya literasi memang sangat penting, sehingga ketika generasi muda jauh dari budaya literasi, jangan salahkan anak cucu, jika mereka lebih mengenal Syahrini, Saskia Gothik, Cita Citata, Soimah, dkk, dibanding Soekarno, HOS Cokroaminoto, Agus Salim, Hadratussyaikh Hasyim Asy'ari, KH Ahmad Dahlan, Tan Malaka, atau tidak tahu sejarah bangsa dan tidak hafal pancasila. Hal itu bukanlah karena tidak ada literatur yang mengulas seputar itu, namun, kebiasaan ini yang tidak ditanamkan sejak dini. Di negara ini, kebanyakan orang membaca buku demi kepraktisan. Kebanyakan orang membaca buku agama karena ingin tahu cara masuk surga. Orang baca buku panduan bisnis karena ingin kaya. Padahal, ada dimensi lain tentang membaca, yakni belajar empati dan perspektif. Masyarakat perkotaan bisa tahu soal kehidupan di desa, misalnya. Lewat baca buku juga bisa mengetahuikrhidupan LGBT, misalnya, dan banyak hal lain yang terjadi dalam hidupini yang tidak terjadi pada kehidupan pribadi seseorang. Pengakuan dan pandangannya mewakili kondisi banyak warga Indonesia yang tidak menyadari betapa pentingnya membaca, terutama karya sastra. Tidak ada yang mampu menyangkal tingkat literasi di Indonesia masih amat rendah.

Selain membaca, kemampuan menulis dalam literasi juga sangat penting. Menulis dapat mengasah kepribadian atau budi pekerti seseorang. Inilah komponen yang sedang dibutuhkan bangsa ini sebagai bangsa yang multikulturalisme. Dimanakarakter toleransi dan empati terhadap segala perbedaan mendapat tempat yang indah untuk dituliskan dan dikenang masyarakatnya. Menulis berarti mengembangkan horizon, yaitu cakrawala tentang 
kemungkinan dunia, yang hendak dibangun di dalam penulisan, serta mengembangkan perangkat dan cara-cara dalam pengembangan horizon tersebut. Menulis adalah mencoba mencari kemungkinan dunia tersebut dengan mengembangkan kemungkinan horizon di dalamnya. Setiap penulis pasti mempunyai sebuah (atau beberapa) horizon, atau dengan perkataan lain harus mengembangkan horizon tersebut, dan mempunyai cara, metode, dan gayanya sendiri dalam penciptaan horizonnya itu. Membaca tidak lagi dianggap sebagai kewajiban, melainkan kebutuhan, dengan memberinya ruang-waktu yang memadai, yang kalau tidak diadakan akan mengakibatkan kondisi lapar pengetahuan. Dengan menulis, seseorang bisa dikenal abadi lewat tulisannya. Kemampuan menulis bisa mengasah seseorang terhadap rasa ingin tahu yang berdampak positif bagi dirinya juga bagi bangsa ini. Menulis adalah proses di mana seseorang bisa menghargai hidup, dengan menulis sesuatu yang bermanfaat setidaknya ada satu atau dua orang akan membaca dan kemudian bermanfaat buat mereka maka itu lah yang di sebut menghargai hidup.

Saat ini tradisi membaca dan menulis harus terus dikembangkan mengingat bahwa melalui membaca, maka kemajuan pendidikan akan lebih pesat. Kemudian melalui kegiatan menulis, ide, gagasan, sertailmu pengetahuan akan terus berkembang. Melalui tulisan ide dan gagasan, akan lebih dikenang sepanjang masa dibandingkan hanya terucapkan secara lisan yang mudah hilang selepas gagasan tersebut dilontarkan. Kebiasaan membaca dan menulis harus terus ditumbuhkan di sekolah-sekolah sebagai dunia akademik, mengingat saat ini pemerintah telah mengeluarkan peraturan bahwa guru yang akan naik pangkat dituntut harus menghasilkan karya tulis. Menulis bagi pendidik sangat penting sebagai contoh mendidik dari segi literasi. Guru yang mampu menginspirasi siswa untuk berkarya adalah guru kekinian. Guru sebagai model harus dipaksa dan terbiasa untuk menulis. Apapun bentuknya. Karya ilmiah, fiksi, buku cerita, bahkan puisi, sangat membantu pendidik untuk memberikan inspirasi bagi peserta didiknya. Dengan begitu, membiasakan budaya literasi bukan hal mustahil untuk dilakukan.

\subsection{Gerakan Literasi Sekolah}

Pendidikan yang berkualitas menjadi kebutuhan penting di era persaingan global yang kian kompetitif. Para pengambil kebijakan di tingkat pusat pastinya sudah menyadari akan hal tersebut. Untuk menjadikan dunia pendidikan berkualitas, tentu sangat banyak faktor yang berkaitan dan saling memengaruhi. Salah satu upaya pemerintah menjadikan pendidikan berkualitas adalah melalui meningkatkan budaya literasi (membaca dan menulis). Pemerintah melalui Permendikbud Nomor 23 Tahun 2015 telah menyadari pentingnya penumbuhan karakter peserta didik melalui kebijakan membaca selama 15 menit sebelum pelajaran dimulai. Namun untuk menyukseskan rencana besar ini, tidak bisa instant dan bersifat temporary. Yang akan dibangun itu adalah kebiasaan, maka dibutuhkan suatu pembiasaan yang harus terus menerus dilakukan sejak usia dini dan untuk itu konsistensi sangat diperlukan. Tentu tugas ini terasa berat untuk diterapkan kepada siswa manakala gurunya tidak ikut terbiasa membaca buku. Ada banyak kegiatan pembiasaan untuk memulai gerakan literasi sekolah, yang terpenting adalah kemauan dari seluruh warga sekolah untuk mensukseskan program tersebut, diantaranya mendekatkan buku sedekat mungkin dengan anak-anak, kemudahan dalam mengakses buku seperti adanya gerobak baca, tersedianya sudut baca maupun lainnya dan tentu saja adanya suplai buku seperti hibah buku dari wali murid maupun masyarakat lainnya. Dalam mensukseskan program literasi sekolah, tentu harus adanya keteladanan dari semua pihak, bukan hanya guru, tetapi juga kepala sekolah, sampai penjaga sekolah. Keteladanan 
hadir agar dapat menumbuhkembangkan minat baca anak yang rendah. Ketika peserta didik melihat gurunya membaca, maka dengan sendirinya di alam bawah sadar, siswapun berkeinginan untuk melakukan hal yang sama. Semua itu butuh komitmen dan perjuangan dari semua pihak untuk mensukseskan gerakan literasi sekolah. Tanpa itu semua, gerakan literasi sekolah akan menguap begitu saja sebagaimana program-program lain yang dicanangkan pemerintah sebelumnya.

Untuk menumbuhkan budaya membaca di masyarakat, sistem pendidikan di Indonesia mungkin bisa meniru negara Vietnam. Negara ini pernah mengalami konflik perang saudara berkepanjangan yang menghancurkan hampir setiap lini kehidupan. Namun, warganya tak lantas tinggal diam. Mereka kembali membangun negaranya, terutama tentang pendidikannya yang harus direformasi. Melalui metode gerakan masyarakat mengumpulkan donasi dan buku, serta menyebarkan melalui pendirian perpustakaan di seluruh pelosok negara tersebut. Kini bisa dilihat hasilnya saat ini yaitu kemajuan negara Vietnam yang cukup pesat di Asia Tenggara. Indonesia tidak boleh kalah dalam hal ini, karena mengingat sumberdaya manusia Indonesia sangat berpotensi menjadi yang terdepan tidak hanya di kawasan Asia Tenggara, namun di lingkup Asia bahkan Dunia. Untuk itu, gerakan literasi yang sekarang ini marak, tidak hanya dibebankan tanggung jawabnya kepada pemerintah semata. Karena untuk membangun suatu kebiasaan justru dimulai dari unit terkecil di masyarakat yaitu keluarga. Saya belum memiliki data ilmiah tentang upaya penumbuhan budaya membaca di keluarga, tapi saya meyakini bahwa keluarga di Indonesia (baik di perkotaan, apalagi di pedesaan), masih belum sepenuhnya menyadari pentingnya budaya membaca apabila dilihat dari indikator persentase pengeluaran keluarga untuk membeli buku.

Sesungguhnya gerakan literasi di Indonesia sudah dimulai pada zaman kependudukan Belanda, tradisi intelektual ini sudah dimunculkan sejak tingkat sekolah. SiswaAMS (sekolah Belanda) diwajibkan harus membaca 25 judul buku sebelum mereka lulus. Dengan kebijakan seperti itu kita bisa melihat hasilnya yaitu tradisi intelektual yang kuat dari para tokoh-tokoh pergerakan kemerdekaan yang mencicipi sistem persekolahan Belanda tersebut. Budaya literasi harus benar-benar tumbuh dan berkembang. Komponen literasi tersebut dijelaskan sebagai berikut:

1. Literasi Dini [Early Literacy (Clay, 2001)], yaitu kemampuan untuk menyimak, memahami bahasa lisan, dan berkomunikasi melalui gambar dan lisan yang dibentuk oleh pengalamannya berinteraksi dengan lingkungan sosialnya di rumah. Pengalaman peserta didik dalam berkomunikasi dengan bahasa ibu menjadi fondasi perkembangan literasi dasar.

2. Literasi Dasar (Basic Literacy), yaitu kemampuan untuk mendengarkan, berbicara, membaca, menulis, dan menghitung (counting) berkaitan dengan kemampuan analisis untuk memperhitungkan (calculating), mempersepsikan informasi (perceiving), mengomunikasikan, serta menggambarkan informasi (drawing) berdasarkan pemahaman dan pengambilan kesimpulan pribadi.

3. Literasi Perpustakaan (Library Literacy), antara lain, memberikan pemahaman cara membedakan bacaan fiksi dan nonfiksi, memanfaatkan koleksi referensi dan periodikal, memahami Dewey Decimal System sebagai klasifikasi pengetahuan yang memudahkan dalam menggunakan perpustakaan, memahami penggunaan katalog dan pengindeksan, hingga memiliki 
pengetahuan dalam memahami informasi ketika sedang menyelesaikan sebuah tulisan, penelitian, pekerjaan, atau mengatasi masalah.

4. Literasi Media (Media Literacy), yaitu kemampuan untuk mengetahui berbagai bentuk media yang berbeda, seperti media cetak, media elektronik (media radio, media televisi), media digital (media internet), dan memahami tujuan penggunaannya.

5. Literasi Teknologi (Technology Literacy), yaitu kemampuan memahami kelengkapan yang mengikuti teknologi seperti peranti keras (hardware), peranti lunak (software), serta etika dan etiket dalam memanfaatkan teknologi.

6. Literasi Visual(Visual Literacy), adalah pemahaman tingkat lanjut antara literasi media dan literasi teknologi, yang mengembangkan kemampuan dan kebutuhan belajar dengan memanfaatkan materi visual dan audiovisual secara kritis dan bermartabat. Tafsir terhadap materi visual yang tidak terbendung, baik dalam bentuk cetak, auditori, maupun digital (perpaduan ketiganya disebut teks multimodal), perlu dikelola dengan baik. Bagaimanapun di dalamnya banyak manipulasi dan hiburan yang benarbenar perlu disaring berdasarkan etika dan kepatutan.

Penguasaan literasi dalam segala aspek kehidupan memang menjadi tulung punggung kemajuan peradaban suatu bangsa. Tidak mungkin menjadi bangsa yang besar, apabila hanya mengandalkan budaya oral yang mewarnai pembelajaran di lembaga sekolah maupun perguruan tinggi. Namun disinyalir bahwa tingkat literasi khususnya dikalangan sekolah semakin tidak diminati, hal ini jangan sampai menunjukkan ketidakmampuan dalam mengelola sistem pendidikan yang mencerdaskan kehidupan bangsa. Karena itulah sudah saatnya, budaya literasi harus lebih ditanamkan sejak usia dini agar anak bisa mengenal bahan bacaan dan menguasai dunia tulis-menulis.

Terobosan penting dalam melaksanakan praktik pendidikan di sekolah agar semua warganya tumbuh sebagai pembelajar sepanjang hayat, Kementerian Pendidikan dan Kebudayaan mengembangkan suatu gerakan yang disebut Gerakan Literasi Sekolah (GLS).Literasi adalah keberaksaraan, yaitu kemampuan membaca dan menulis. Budaya literasi dimaksudkan untuk melakukan kebiasaan berfikir yang diawali dengan kegiatan membaca dan menulis hingga tercipta sebuah karya bahkan terjadinya perubahan tingkah laku dan budi pekerti yang baik.Gerakan Literasi Sekolah (GLS) adalah sebuah upaya yang dilakukan secara menyeluruh dan berkelanjutan untuk menjadikan sekolah sebagai organisasi pembelajaran yang warganya literat sepanjang hayat melalui pelibatan publik mulai dari semua pemangku kepentingan di bidang pendidikan, dari tingkat pusat, provinsi, kabupaten/kota, hingga satuan pendidikan (peserta didik, guru, kepala sekolah, tenaga kependidikan, pengawas sekolah) juga melibatkan Komite Sekolah, orang tua/wali murid peserta didik), akademisi, penerbit, media massa, masyarakat (tokoh masyarakat yang dapat merepresentasikan keteladanan, dunia usaha, dll.)

Gerakan Literasi Sekolah (GLS) memperkuat gerakan penumbuhan budi pekerti sebagaimana dituangkan dalam Peraturan Menteri Pendidikan dan Kebudayaan Nomor 23 Tahun 2015. Salah satu kegiatan di dalam gerakan tersebut adalah kegiatan 15 menit membaca buku nonpelajaran sebelum waktu belajar dimulai. Kegiatan ini dilaksanakan untuk menumbuhkan minat baca peserta didik serta meningkatkan keterampilan membaca agar pengetahuan dapat dikuasai secara lebih baik. Materi baca berisi nilai-nilai budi pekerti, berupa 
kearifan lokal, nasional, dan global yang disampaikan sesuai tahap perkembangan peserta didik.Gerakan Literasi Sekolah (GLS) diharapkan mampu menggerakkan warga sekolah, pemangku kepentingan, dan masyarakat untuk bersama-sama memiliki, melaksanakan, dan menjadikan gerakan ini sebagai bagian penting dalam kehidupan. Mengacu pada metode pembelajaran Kurikulum 2013 yang menempatkan peserta didik sebagai subjek pembelajaran dan guru sebagai fasilitator, kegiatan literasi tidak lagi berfokus pada peserta didik semata. Guru, selain sebagai fasilitator, juga menjadi subjek pembelajaran. Akses yang luas pada sumber informasi, baik di dunia nyata maupun dunia maya dapat menjadikan peserta didik lebih tahu daripada guru. Oleh sebab itu, kegiatan peserta dalam berliterasi semestinya tidak lepas dari kontribusi guru, dan guru sebaiknya berupaya menjadi fasilitator yang berkualitas. Guru dan pemangku kebijakan sekolah merupakan figur teladan literasi di sekolah.

Tujuan Umum Gerakan Literasi Sekolah (GLS) adalah menumbuhkembangkan budi pekerti peserta didik melalui pembudayaan ekosistem literasi sekolah yang diwujudkan dalam Gerakan Literasi Sekolah agar mereka menjadi pembelajar sepanjang hayat.Tujuan Khusus Gerakan Literasi Sekolah (GLS) adalah: (a) menumbuhkembangkan budaya literasi di sekolah. (b) Meningkatkan kapasitas warga dan lingkungan sekolah agar literat. (c) menjadikan sekolah sebagai taman belajar yang menyenangkan dan ramah anak agar warga sekolah mampu mengelola pengetahuan. (d) menjaga keberlanjutan pembelajaran dengan menghadirkan beragam buku bacaan dan mewadahi berbagai strategi membaca. Adapun prinsip-prinsip gerakan literasi sekolah yakni :

1. Sesuai dengan tahapan perkembangan peserta didik berdasarkan karakteristiknya

2. Dilaksanakan secara berimbang; menggunakan berbagai ragam teks dan memperhatikan kebutuhan peserta didik

3. Berlangsung secara terintegrasi dan holistik di semua area kurikulum

4. Kegiatan literasi dilakukan secara berkelanjutan

5. Melibatkan kecakapan berkomunikasilisan

6. Mempertimbangkan keberagaman

Merujuk pada kedua tujuan diatas bahwa Gerakan Literasi Sekolah (GLS) harus dilaksanakan secara kolaboratif oleh seluruh komponen yang ada di sekolah maupun masyarakat diluar sekolah. Artinya GLS harus mampu menggerakan seluruh komponen internal maupun eksternal sekolah. Seiring kemajuan teknologi gerakan literasi ini tidak sekadar kegiatan membaca dan menulis saja, namun mencakup kepada kemampuan seseorang mengadopsi informasi dari berbagai sumber baik audio, video, cetak ataupun elektronik.

Pembelajaran berbasis budaya literasi akan mengondisikan peserta didik untuk menjadi seorang literat. Peningkatan kemampuan literasi dalam belajar sejalan dengan tujuan pendidikan, yaitu berkembangnya potensi peserta didik agar menjadi manusia yang beriman dan bertaqwa kepada Tuhan Yang Maha Esa, berahlak mulia, sehat, berilmu, cakap, kreatif, mandiri, dan menjadi warga negara yang demokratis serta bertanggung jawab (Depdiknas, 2003). Pemerolehan tujuan ini dapat dilakukan siswa jika mereka telah menjadi sosok literat. Para siswa memiliki bekal literasi dalam dirinya sehingga mampu melengkapi diri dengan kemampuan yang diharapkan.

Dalam rangka mengimplementasikan Gerakan Literasi Sekolah (GLS), maka sekolah bisa mengukur dan merencanakan tentang kegiatan literasi seperti apa yang bisa diterapkan. Hal ini tentu tergantung kepada sarana dan prasarana pendukung disebuah 
sekolah. Sementara itu seluruh warga sekolah harus punya komitmen dan keteladanan terhadap seluruh peserta didik tentang upaya menjadikan sekolah sebagai lingkungan yang literat sehingga prilaku warga sekolah bermartabat.

\section{SIMPULAN}

Dimulainya literasi dengan serius dan berkelanjutan di sekolah, keluarga, dan masyarakat sejak dini, bukan mustahil kualitas sumber daya dan pendidikan di Indonesia mulai berbenah kearah yang lebih baik. Pendidikan dan budaya literasi Indonesia akan tumbuh lebih baik dari negara-negara yang telah lebih dulu peka dan mengaplikasikan literasi ini sebagai kebiasaan dan kebutuhan dalam hidup, salah satunya kota Ohio, Amerika Serikat. Indonesia bisa belajar banyak dari budaya ini. Semua orang membaca buku, majalah, atau surat kabar harian di halte, di bus kota, atau di kafe-kafe. Orang tua atau generasi muda duduk di taman kota sambil menikmati buku atau novel ratusan halaman. Siswa merasa malu jika tidak membaca. Mahasiswa menjadikan membaca dan menulis sebagai tradisi ilmiah, sedangkan diskusi menjadi rutinitasnya. Perpustakaan bukan satu-satunya tempat untuk membaca. Bagi mereka membaca dan menulis sudah menjadi budaya yang bisa dilakukan dimana saja dan kapan saja. Di Columbus, Ohio, Amerika Serikat, upaya menjadikan membaca dan menulis sebagai budaya sudah dimulai sejak puluhan tahun silam. Dinas Pendidikan mendorong sekolah untuk merancang kurikulum dan program pembelajaran yang mengarah pada stimulus anak mencintai membaca dan menulis sejak usia dini. Bahkan banyak program yang melatih orang tua untuk membaca cerita-cerita dongeng kepada anaknya di rumah.

Orang tua yang memiliki anak usia balita selain menyekolahkan anaknya di Taman Kanak-Kanak atau menitipkannya di Taman Penitipan Anak (Children's Day Care), mereka juga belajar bagaimana mendukung perkembangan membaca dan menulis anak di rumah secara efektif.Dan program-program tersebut dilaksanakan gratis oleh pemerintah lokal secara berkala.Di sekolah TK, guru-guru dengan kreatifnya membacakan cerita kepada anak-anak di setiap awal pembelajaran. Kegiatan ini juga diikuti dengan latihan pelafalan kalimat dengan penekanan dan intonasi yang tepat. Banyak penelitian yang sudah membuktikan efektifitas kegiatan semacam ini dalam meningkatkan kemampuan bahasa anak yang mengarah padakemampuan membaca dan menulis mereka.

Di tingkat SD kelas satu sampai dengan tiga, setiap siswa diwajibkan membaca dan menulis di rumah melalui penerapan tugas membaca mandiri. Setiap siswa punya readinglog, semacam buku harian membaca, yang berisi berapa lama waktu yang siswa habiskan untuk membaca di rumah dan paraf orang tuanya. Tidak ada patokan menit atau jam. Buku harian itu juga berisi tugas-tugas sekolah lainnya yang harus dikerjakan di rumah seperti menulis. Pada usia ini siswa diharuskan menulis paragraf pendek tentang apa yang sudah dibaca. Saat di sekolah mereka akan diminta untuk menceritakan bacaannya di depan kelas atau di kelompok kecil. Sekolah juga masih menerapkan latihan pelafalan kata atau kalimat yang baik dan benar pada usia ini. Sedangkan pada kelas empat sampai dengan enam, ada waktu minimal yang ditetapkan sekolah. Untuk kelas lima misalnya, siswa harus membaca di rumah minimal selama 25 menit sehari dengan pantauan orang tua. Dan kewajiban menulis pada level ini mengharuskan siswa menulis esai yang biasanya terintegrasi dengan pelajaran IPA atau IPS.

Kewajiban membaca ini terus berlanjut sampai level SMP dan SMA. Yang membedakannya adalah bahan bacaan dan batasan minimal waktunya. Di SMP misalnya, siswa diharuskan membaca buku atau novel kemudian diwajibkan menulis laporan bacaannya di buku harian mereka. Setiap 
sekolah menerapkan aktivitas yang berbeda dalam rangka membiasakan anak untuk membaca dan menulis. Sekolah diberi otoritas untuk merancang kegiatan literasi ini dengan sentuhan kreatifitas dengan tetap memperhatikan kualitas dan efektifitas kegiatan.

\section{DAFTAR PUSTAKA}

Alwasilah, A. Chaedar. 2001. Membangun Kota Berbudaya Literat. Jakarta: Media Indonesia.

Direktorat Jenderal Pendidikan Dasar dan Menengah Kementrian Pendidikan dan Kebudayaan.2015. Buku Saku Gerakan Literasi Sekolah. Jakarta: Satgas GLS.
Joyce, Bruce dan Marsha Weil. 1986. Models of Teaching. Third Edition. New Jersey: Prentice-Hall. Inc. Englewood Cliffs.

Goleman, Daniel. 1997. Emotional Intelligence (Kecerdasan Emosional). Jakarta: Gramedia Pustaka Utama.

Tierney, R. J., J. E. Readence, dan E. K. Dieshner. 1990. Reading Strategies and Practices: A Compendium III. Boston: Allyn and Bacon.

Vacca, Richard T. dan Jo Anne L. Vacca. 1989. Content Area Reading. London: Scott, Foresman and Company. 